\title{
PENGEMBANGAN BAHAN AJAR MENYIMAK BERBASIS MEDIA AUDIO VISUAL DENGAN PEGINTEGRASIAN PENDIDIKAN KARAKTER POSITIF PESERTA DIDIK KELAS V SEKOLAH DASAR
}

\author{
Foni Yulia Putri ${ }^{1}$, Ramalis Hakim ${ }^{2}$, Desyandri $^{3}$, Darnis Arief ${ }^{4}$, Risda Amini ${ }^{5}$ \\ Yeni Erita ${ }^{6}$ \\ ${ }^{1}$ SDN Jakenan, Pati, Indonesia \\ ${ }^{2}$ SDN 31 Jati Tanah Tinggi, Padang, Indonesia \\ 3,4,5,6 Universitas Negeri Padang, Padang, Indonesia \\ ${ }^{1}$ fyuliaputri@gmail.com, ${ }^{2}$ ramalishakim@gmail.com, ${ }^{3}$ desyandri@fip.unp.ac.id, ${ }^{4}$ nis.darnis@gmail.com, \\ ${ }^{5}$ risdamini@fip.unp.ac.id, ${ }^{6}$ yenierita@fip.unp.ac.id
}

\begin{abstract}
ABSTRAK
Penelitian ini dilatarbelakangi oleh rendahnya kemampuan menyimak siswa. Hal ini disebabkan oleh kurang tepatnya bahan ajar untuk meningkatkan kemampuan menyimak siswa. Mengembangkan bahan ajar menyimak berbasis media audio visual diharapkan dapat meningkatkan kemampuan menyimak siswa. Berdasarkan hal tersebut dikembangkan bahan ajar menyimak berbasis media audio visual dengan pengintegrasikan pendidikan karakter positif peserta didik kelas V sekolah dasar. Tujuan yang hendaknya dicapai dalam pengembangan bahan ajar ini adalah untuk menghasilkan bahan ajar menyimak berbasis media audio visual yang valid, praktis, dan efektif. Jenis penelitian adalah penelitian pengembangan (research and development). Model pengembangan yang digunakan yaitu model 4-D yang terdiri dari tahap pendefinisian (define), perancangan (design), pengembangan (development), dan penyebaran (disseminate). Data penelitian dari uji validitas diperoleh melalui lembar validasi RPP dan bahan ajar. Data kepraktisan dikumpul melalui lembar observasi keterlaksanaan RPP dan angket respon guru serta siswa. Keefektifan dilihat dari aktivitas dan proses hasil belajar siswa berupa penilaian karakter dan keterampilan menyimak siswa. Data yang terkumpul dianalisis secara deskriptif. Hasil penelitian dari uji validitas yang dilakukan menunjukkan bahwa bahan ajar yang dihasilkan sangat valid. Hasil observasi, angket, dan wawancara dengan guru juga menyatakan bahwa bahan ajar ini praktis. Pada tahap uji efektivitas, didapatkan hasil rata-rata. Hasil penilaian keterampilan menyimak berbasis media audio visual siswa untuk penilaian keterampilan proses juga telah berada pada kategori sangat baik, dan didapatkan hasil bahwa 93\% siswa mampu menyimak berbasis media audio visual. Berdasarkan hasil tersebut, dapat disimpulkan bahwa bahan ajar menyimak berbasis media audio visual untuk kelas V SD yang telah dihasilkan dapat dinyatakan valid, praktis, dan efektif.
\end{abstract}

Kata Kunci: keterampilan menyimak, media audio visual

\section{DEVELOPING AUDIO VISUAL MEDIA BASED LISTENING MATERIALS THROUGH THE INTEGRATION OF POSITIVE CHARACTER EDUCATION FOR GRADE V ELEMENTARY SCHOOL STUDENTS}

\begin{abstract}
This research was motivated by the students' low listening ability, which was caused by inappropriate teaching materials to improve students' listening ability. Developing listening materials based on audio-visual media was expected to improve students' listening skills. The listening materials based on audio-visual media were developed with the integration of positive character education for fifth-grade elementary school students. The goal that should be achieved in the development of this teaching material was to produce valid, practical, and effective listening materials based on audio-visual media. This type of research was research and development utilizing the 4-D model which consisted of the stages of defining, designing, developing, and disseminating. The research data from the validity test were obtained through the RPP validation sheet and teaching materials. The data practicality was collected through the lesson plan implementation, observation sheet, and teacher and student response questionnaires. The effectiveness was seen from the activities and process of students' learning outcomes in the form of character assessment and students' listening skills. The collected data were analyzed descriptively. The results of the validity test showed that the teaching materials produced were very valid. The results of observations, questionnaires, and interviews with teachers also stated that this teaching material was practical. Meanwhile, the effectiveness test obtained the average results. The results of the assessment of listening skills based on audiovisual media were also in the very good category, and it was found that 93\% of students were able to listen based on audiovisual media. Based on these results, it can be concluded that the listening materials based on audiovisual media for grade V SD can be declared valid, practical, and effective.
\end{abstract}

Keywords: listening skills, audio visual media

\begin{tabular}{|c|c|c|}
\hline Submitted & Accepted & Published \\
\hline 15 Februari 2021 & 04 Juli 2021 & 24 November 2021 \\
\hline
\end{tabular}

\begin{tabular}{|l|l|c|c|}
\hline Citation & $:$ & $\begin{array}{c}\text { Putri, F.Y., Hakim, R., Desyandri, D., Arief, D., Amini, R., \& Erita, Y. (2021). Pengembangan Bahan Ajar Menyimak } \\
\text { Berbasis Media Audio Visual Dengan Pegintegrasian Pendidikan Karakter Positif Peserta Didik Kelas V Sekolah }\end{array}$ \\
& & $\begin{array}{l}\text { Dasar. Jurnal PAJAR (Pendidikan dan Pengajaran), 5(6), 1638-1647. } \\
\text { http://dx.doi.org/10.33578/pjr.v5i6.8325. }\end{array}$ \\
\hline
\end{tabular}




\section{PENDAHULUAN}

Ilmu sangat penting dalam kehidupan, sehingga kita diwajibkan untuk menuntutnya. Bahasa diperlukan dalam menuntut ilmu. Bahasa merupakan alat komunikasi yang sangat penting, dengan bahasa, manusia dapat menyatakan perasaan, pendapat, serta berfikir dengan bernalar. Agar komunikasi berjalan dengan lancar dan tidak menimbulkan salah paham manusia perlu terampil berbahasa. Dalam kehidupan dituntut setiap orang harus memiliki berbagai pengetahuan agar kehidupan bisa berjalan dengan mudah. Begitu juga dengan pengetahuan bahasa. Semua kegiatan dalam masyarakat tidak terlepas dari bahasa. Semua orang menyadari bahwa interaksi sesama manusia memerlukan bahasa untuk berkomunikasi. Melalui bahasa, manusia dapat berekspresi, menyampaikan pesan, ide, gagasan, atau pendapat.

Manusia dituntut untuk menguasai keterampilan berbahasa. Keterampilan tersebut meliputi menyimak, berbicara, membaca, dan menulis. Keempat keterampilan berbahasa ini tidak dapat dipisahkan satu sama lain. Di antara keempat keterampilan tersebut, yang menjadi salah satu sorotan utama adalah keterampilan menyimak. Keterampilan menyimak sangat berkaitan dengan proses berpikir yang mendasari bahasa dengan bahasa lisan. Menyimak merupakan keterampilan yang pertama dialami manusia dari keterampilan lainnya.

Keterampilan menyimak merupakan aktivitas yang paling awal dilakukan oleh manusia bila dilihat dari proses pemerolehan bahasa. Sebelum anak dapat melakukan berbicara, membaca apalagi menulis, kegiatan menyimaklah yang pertama kali dilakukan (Tarigan, 2008:2). Sejalan dengan hal tersebut Saddhono (2014:17) mengatakan keterampilan menyimak merupakan aktivitas atau kegiatan awal dilakukan oleh anak manusia bila dilihat dari proses pemerolehan keterampilan bahasa.

Aktivitas menyimak menduduki porsi terbesar dari waktu keseharian hidup manusia. Menurut Bird hasil penelitiannya bahwa seorang mahasiswa pada perguruan tinggi dalam perkuliahan membagi aktivitasnya sebagai berikut : menyimak $42 \%$, berbicara $25 \%$, membaca $15 \%$, dan menulis 18\% (dikutip Saddhono 2014:19). Seiring yang dikemukakan oleh Rankin pada umumnya seseorang menggunakan $45 \%$ waktunya untuk menyimak, 30\% untuk berbicara, $16 \%$ membaca, dan hanya 9\% saja untuk menulis (dikutip Tarigan 2008:139). Berdasarkan hasil penelitan tersebut sudah terlihat jelas keberhasilan seorang siswa itu diawali dengan bagaimana pemerolehan keterampilan menyimak siswa.

Oleh sebab itu, keterampilan menyimak merupakan salah satu keterampilan berbahasa yang harus dikuasai oleh anak sebelum menguasai keterampilan lainnya. Kegiatan menyimak mempunyai peranan yang sangat penting dalam proses pembelajaran di SD sebab kemampuan menyimak yang baik adalah kondisi awal untuk menghasilkan prestasi belajar yang baik. Kegiatan menyimak juga dapat menambah ilmu atau wawasan peserta didik. Kegiatan ini dapat dilakukan melalui radio, tv, atau langsung dari narasumbernya. Melalui proses menyimaklah seseorang mengenal konsep segala informasi baik berupa ilmu pengetahuan maupun hal-hal lain yang belum kita kenal. Di dalam pembelajaran menyimak diharapkan agar peserta didik dapat menangkap dan memahami pesan yang di tuangkan ke dalam ide serta gagasan yang terdapat pada materi atau bahan simakan.

Untuk mencapai hal itu, maka proses pembelajaran menyimak dibuat semenarik mungkin agar peserta didik tertarik dan fokus selama proses pembelajaran. Guru dituntut kreatif dalam merancang proses pembelajaran menyimak. Idealnya dalam pembelajaran menyimak bahan simakan dibacakan atau disajikan oleh guru, baik secara lisan maupun menggunakan media yang mendukung. Karena pada hakekatnya, dalam proses pembelajaran menyimak peserta didik hanya bertindak sebagai penyimak.

Siswa kelas V SD yang rata-rata berusia 9-11 tahun, umumnya menyukai cerita anak. Cerita anak yang bersifat fiktif atau khayalan dan fantasi dapat membawa pikiran dan jiwa mereka memiliki imajinasi terhadap cerita tersebut. Dengan alasan tersebut, cerita anak baik dijadikan bahan ajar untuk mengasah keterampilan menyimak intensif siswa. Hal ini selaras dengan 
Standar Kompetensi dan Kompetensi Dasar pada KTSP 2006 SD/MI kelas V Semester II pada Standar Kompetensi butir 5, yaitu: memahami cerita tentang suatu peristiwa dan cerita pendek anak yang disampaikan secara lisan dan Kompetensi Dasar pada butir 5.2 "Mengidentifikasi unsur cerita: tokoh, tema, latar, amanat" (Depdiknas: 2006).

Pada pembelajaran mengidentifikasi unsur cerita, guru harus menyajikan cerita yang akan diidentifikasi melalui media yang tepat dan menarik bagi peserta didik. Proses pembelajaran menyimak, khususnya menyimak cerita, peserta didik dapat diberikan penanaman/pengembangan karakter positif yang terdapat dalam cerita yang dipelajarinya. Menurut Kemendiknas (2010:4), pengembangan itu harus dilakukan melalui perencanaan yang baik, pendekatan yang sesuai, dan metode belajar serta pembelajaran yang efektif. Sesuai dengan sifat suatu nilai, pendidikan budaya dan karakter bangsa adalah usaha bersama, oleh karenanya harus dilakukan secara bersama oleh semua guru dan pemimpin sekolah, melalui semua mata pelajaran, dan menjadi bagian yang tak terpisahkan dari budaya sekolah.

Namun kenyataan di lapangan, berdasarkan observasi yang peneliti lakukan pada peserta didik kelas V SD Negeri 31 Jati Tanah Tinggi, Kecamatan Padang Timur, guru dalam proses pembelajaran menyimak, khususnya mengidentifikasi unsur dalam sebuah cerita, menyuruh salah satu peserta didik untuk membacakan teks cerita dan peserta didik yang lain menyimak. Dalam proses pembelajaran guru jarang menggunakan media pembelajaran yang menarik dan sesuai dengan materi. Hal tersebut membuat peserta didik menjadi jenuh dan proses pembelajaran menjadi tidak menyenangkan, sehingga peserta didik tidak termotivasi dalam proses pembelajaran berlangsung. Jika hal ini terus terjadi, maka peserta didik akan selalu menghadapi permasalahan yang sama dalam pembelajaran menyimak. Selain itu, dalam proses pembelajaran guru tidak memberikan penanaman sikap positif terhadap cerita yang dipelajari oleh peserta didik.

Kondisi pembelajaran yang tidak efektif dapat mengakibatkan kurangnya keterampilan menyimak peserta didik, maka diperlukan perbaikan terhadap proses pembelajaran terutama bahan ajar yang digunakan guru. Salah satu upaya yang bisa digunakan untuk mengatasi permasalahan di atas, perlunya pemilihan media pembelajaran dengan tepat dan menyenangkan sehingga dalam pembelajaran peserta didik menjadi lebih fokus dan paham terhadap materi yang disajikan guru. Hal ini sejalan dengan pendapat Hamalik (dalam Azhar, 2006:4), bahwa hubungan komunikasi akan berjalan lancar dengan hasil yang maksimal apabila menggunakan alat bantu yang disebut media komunikasi. Penggunaan media sangatlah penting dalam proses pembelajaran, karena dengan menggunakan media peserta didik menjadi bersemangat, termotivasi serta dapat menumbuhkan minat peserta didik dalam pembelajaran. Hal ini senada dengan pendapat Rossi (dalam Wina, 2010:163), media pembelajaran adalah seluruh alat dan bahan yang dapat dipakai untuk mencapai tujuan pendidikan.

Media pembelajaran terdiri dari beberapa jenis. Sejalan dengan pendapat Wina (2008: 112), media dalam pembelajaran sangat beraneka ragam jenisnya, antara lain media audio, media visual, dan media audio visual. Salah satu media yang dapat digunakan dalam pembelajaran menyimak adalah media audio visual. Hal tersebut senada dengan pendapat Syaiful (2006:124), bahwa media audio visual memiliki beberapa keunggulan. Salah satu keunggulan dari media audio visual menurut Hujair (2009:109) yaitu menyajikan obyek secara konkret atau pesan pembelajaran secara realistik, sehingga sangat baik untuk menambah pengalaman belajar.

\section{KAJIAN TEORETIS}

Kegiatan menyimak yang benar ialah melewati tahapan-tahapan mendengar, memahami, menginterpretasi, mengevaluasi, dan menanggapi. Sehingga kegiatan menyimak yang dilakukan siswa sistematis.

Menurut Taufina (2015:11) ada beberapa tahapan menyimak supaya komunikasi tidak terputus atau terjadi kesalahpahaman informasi, berikut tahapan menyimak.

a. Tahap Mendengar (Hearing)

Kita mendengarkan segala sesuatu dari pembicara dan memprosesnya untuk memperoleh 
sebuah informasi yang baru maupun yang sudah kita ketahui.

b. Tahap Memahami (Understanding)

Sekali stimulus tertentu telah dapat dikenal suatu makna, atau identifikasi pun diberikan kepada setiap butir yang ada. Setelah kita mendengarkan pembicaraan pembicara, maka kita akan merasa ingin mengetahui, mengerti, dan memahami apa isi dari informasi yang kita dengarkan.

c. Tahap Menginterpretasi (Interpretating)

Kita mengintegrasikan atau menyatu padukan apa yang kita dengar informasi lain yang telah kita simpan dan rekam dalam otak kita. Oleh karena itulah maka pengetahuan umum sangat penting dalam tahap ini. Karena kalau proses menyimak berlangsung, kita harus terlebih dahulu harus mempunyai beberapa latar belakang atau pemahaman mengenai bidang pokok pesan tertentu.

\section{d. Tahap Mengevaluasi (Evaluating)}

Pada tahap ini, informasi baru yang telah kita terima dikontraskan dan dibandingkan dengan segala informasi yang telah kita miliki mengenai hal tersebut. Proses ini akan menjadi paling mudah berlangsung kalau informasi baru justru menunjang prasangka atau atau prakonsepsi kita.

e. Tahap Menanggapi (Responding)

Pada tahap ini, kita secara aktif mengevaluasi apa-apa yang kita dengar dan menelusuri dari mana datangnya semua itu.Kita mulai menolak dan menyetujui, mengakui dan mempertimbangkan informasi tersebut berikut sumber-sumbernya. Tahap ini adalah tahap terakhir dalam menyimak, dimana penyimak menerima dan menyerap hasil simakan kemudian memberikan respon tanggapan terhadap apa yang disimak, bisa berupa komentar, pertanyaan, dan tanggapan yang lainnya.

Media audio visual merupakan media yang dapat dilihat dan didengar. sejalan dengan Hujair (2009:105), media audio visual adalah seperangkat alat yang dapat memproyeksikan gambar bergerak dan bersuara.Sedangkan menurut Mohammad (2011:102), bahwa media audio visual adalah media penyampaian pesannya dapat yang diterima oleh indera pendengaran dan indera penglihatan yang memproyeksikan unsur suara dan unsur gambar.

Selanjutnya untuk mengembangkan bahan ajar ini penulis mendesain proses pembelajaran dengan mengintegrasikan pendidikan karakter positif. Menurut Kemendiknas (2010:2-4) karakter adalah watak, tabiat, akhlak, atau kepribadian seserorang yang terbentuk dari hasil internalisasi berbagai kebajikan (virtues) yang diyakini dan digunkaan sebagai landasan untuk cara pandang, berpikir, bersikap, dan bertindak. Pengembangan budaya dan karakter bangsa hanya dapat dilakukan dalam suatu proses pendidikan yang tidak melapaskan peserta didik dari lingkungan sosial, budaya masyarakat, dan budaya bangsa.

\section{METODE PENELITIAN}

Model pengembangan yang digunakan pada penelitian ini adalah model 4-D. (four $D$ models) sebagaimana dikemukakan (Fauziah, Sulaeman, \& Chandra, 2020) model ini terdiri dari empat tahap yaitu pendefenisian (Define) yaitu mendefenisikan tentang kebutuhan sumber belajar serta kebutuhan siswa, perancangan (Design) proses pembelajaran yang menarik bagi siswa, pengembangan (Development) melakukan uji kelayakan oleh validator ahli dan praktisi yang mengampuni bahan ajar dan keterampilan menulis, dan penyebaran (Disseminate) melakukan uji coba atas produk yang telah dinyatakan valid oleh validator. Penelitian dilaksanakan di SDN 31 Jati Tanah Tinggi dan 15 Jati Tanah Tinggi. Penelitian dilaksanakan 3 April - 29 April 2017. Dengan mengunakan intrumen-instrumen yang telah divalidasi oleh validator ahli dan praktisi berupa instrumen Validasi Bahan Ajar, respon guru dan peserta didik terhadap praktikalitas bahan ajar, aktivitas peserta didik, dan observasi penggunaan bahan ajar.

\section{HASIL DAN PEMBAHASAN}

Hasil penelitian ini dimulai dengan proses validasi instrumen yang akan digunakan dalam proses pengembangan bahan ajar menyimak berbasis media audio visual dengan pengintegrasian pendidikan karakter positif di mana hasil yang diperoleh . 
Jurnal PAJAR (Pendidikan dan Pengajaran)

Volume 5 Nomor 6 November | ISSN Cetak : 2580 - 8435| |ISSN Online : 2614 - 1337

DOI : http://dx.doi.org/10.33578/pjr.v5i6.8325

Tabel 1. Hasil Penilaian Instrumen oleh Validator Ahli

\begin{tabular}{|c|c|c|c|c|c|c|}
\hline \multirow[t]{2}{*}{ No } & \multirow[t]{2}{*}{ Instrumen } & \multicolumn{3}{|c|}{$\begin{array}{c}\text { Jumlah Skor Penilaian dari } \\
\text { Validator }\end{array}$} & \multirow[t]{2}{*}{$\begin{array}{c}\text { Rata-rata } \\
(\%)\end{array}$} & \multirow[t]{2}{*}{ Kategori } \\
\hline & & V1 & V2 & V3 & & \\
\hline 1 & Validasi bahan ajar. & $78.6 \%$ & $92.9 \%$ & $75.0 \%$ & 82.2 & Sangat Valid \\
\hline 2 & $\begin{array}{l}\text { Lembar respon guru terhadap } \\
\text { praktikalitas bahan ajar. }\end{array}$ & $92.9 \%$ & $92.9 \%$ & $53.6 \%$ & 79.8 & Valid \\
\hline 3 & $\begin{array}{l}\text { Lembar respon peserta didik } \\
\text { terhadap praktikalitas. }\end{array}$ & $92.9 \%$ & $85.7 \%$ & $89.3 \%$ & 89.3 & Sangat Valid \\
\hline 4 & Lembar observasi pembelajaran. & $85.7 \%$ & $85.7 \%$ & $57.1 \%$ & 76.2 & Valid \\
\hline 5 & $\begin{array}{l}\text { Lembar observasi aktivitas } \\
\text { peserta didik menggunakan } \\
\text { bahan ajar }\end{array}$ & $92.9 \%$ & $85.7 \%$ & $46.4 \%$ & 75 & Valid \\
\hline
\end{tabular}

Selanjutnya, setelah melakukan proses validasi instrumen maka akan dilakukan proses validasi bahan ajar. Berikut hasil validasi bahan ajar.

Tabel 2. Hasil Validasi Bahan Ajar oleh Validator Ahli

\begin{tabular}{lccc}
\hline & & Nilai & \\
No & Aspek yang Dinilai & Validasi (\%) & Kategori \\
\hline 1 & Aspek isi & $88.6 \%$ & Sangat Valid \\
2 & Aspek kebahasaan & $83.3 \%$ & Sangat Valid \\
3 & Aspek penyajian & $83.3 \%$ & Sangat Valid \\
4 & Aspek kegrafikaan & $80 \%$ & Valid \\
& Rata-rata & $\mathbf{8 3 . 8 \%}$ & Sangat Valid \\
\hline
\end{tabular}

Sebagaimana tabel 2 diperoleh hasil validasi dengan kategori sangat valid maka bahan ajar akan diujicobakan pada siswa kelas V sekolah dasar dengan mengikuti tahapan dari menyimak berbasis media audio visual dengan pengintegrasian karakter positif yang telah dikembangkan pada bahan ajar yang digunakan.
Proses pembelajaran yang dilakukan meliputi aspek penilaian berdasarkan pada indikator penilaian menyimak berbasis media audio visual. Berikut ini hasil dari proses menyimak berbasis media audio visual pada tahapan ujicoba.

Tabel 3. Hasil Observasi Aktivitas Peserta Didik Uji Coba

\begin{tabular}{cccccc}
\hline \multirow{2}{*}{ No } & Pertemuan & \multicolumn{2}{c}{$\begin{array}{c}\text { Aktivitas yang } \\
\text { diamati }\end{array}$} & $\begin{array}{c}\text { Rata-rata } \\
(\%)\end{array}$ & Kategori \\
\cline { 3 - 4 } & & $\begin{array}{l}\text { Visual } \\
\text { Activiti }\end{array}$ & $\begin{array}{c}\text { Oral } \\
\text { Activi }\end{array}$ & & \\
& & es & ties & & \\
& & 89 & 72 & $80.5 \%$ & Baik \\
& & 72.2 & 83.3 & $77.8 \%$ & Baik \\
\hline 1 & Pertemuan I & 89 & $86 \%$ & Sangat Baik \\
2 & Pertemuan II & Sangat Baik \\
\hline
\end{tabular}


Jurnal PAJAR (Pendidikan dan Pengajaran)

Volume 5 Nomor 6 November | ISSN Cetak : 2580 - 8435| |ISSN Online : 2614 - 1337

DOI : http://dx.doi.org/10.33578/pjr.v5i6.8325

Tabel 4. Hasil Penilaian Proses Keterampilan Menyimak Uji Coba

\begin{tabular}{clccccc}
\hline \multirow{2}{*}{ No } & \multicolumn{1}{c}{ Penilaian } & \multicolumn{2}{c}{ Nilai Rata-rata Kelas (\%) } & Rata- & Kategori \\
\cline { 2 - 4 } & \multicolumn{1}{c}{ Menyimak } & $\begin{array}{c}\text { LKS } \\
\text { I }\end{array}$ & $\begin{array}{c}\text { LKS } \\
\text { II }\end{array}$ & $\begin{array}{c}\text { LKS } \\
\text { III }\end{array}$ & & \\
\hline 1 & $\begin{array}{l}\text { Mengidentifikasi } \\
\text { tokoh }\end{array}$ & 92.5 & 90 & 97.5 & 93.3 & $\begin{array}{c}\text { Sangat } \\
\text { Tinggi }\end{array}$ \\
2 & $\begin{array}{l}\text { Mengidentifikasi } \\
\text { latar }\end{array}$ & 80 & 75 & 80 & 78.3 & Tinggi \\
3 & $\begin{array}{l}\text { Mengidentifikasi } \\
\text { tema }\end{array}$ & 82.5 & 82.5 & 77.5 & 80.9 & Tinggi \\
4 & $\begin{array}{l}\text { Mengidentifikasi } \\
\text { amanat }\end{array}$ & 85 & 87.5 & 82.5 & 85 & $\begin{array}{l}\text { Sangat } \\
\text { Tinggi } \\
\text { Menyimpulkan }\end{array}$ \\
$\begin{array}{l}\text { isi cerita } \\
\text { Rata-rata }\end{array}$ & 77.5 & 82.5 & 80 & 80 & $\begin{array}{c}\text { Sangat } \\
\text { Tinggi } \\
\text { Sangat } \\
\text { Tinggi }\end{array}$ \\
\hline
\end{tabular}

Tabel 3 dan 4 menunjukkan bahwa pertemuan ke-1, ke-2 dan ke-3 pada sekolah uji coba hasil observasi aktivitas peserta didik memiliki rata-rata $81.4 \%$ denga kategori sangat baik dan hasil penilaian proses Keterampilan Menyimak secara keseluruhan memiliki rata-rata persentase $83.5 \%$ dengan kategori sangat tinggi. Artinya, ketika proses pebelajaran berlangsung, aktivitas peserta didik sangat baik dalam memahami dan menggunakan bahan ajar yang dikembangkan.

Selanjutnya pada sekolah penyebaran hasilnya menunjukan peningkatan yang baik. Berikut ini hasil observasi aktivitas peserta didik dan penilaian proses keterampilan menyimak pada sekolah penyebaran.

Tabel 5. Hasil Observasi Aktivitas Peserta Didik Penyebaran

\begin{tabular}{lccccc}
\hline $\mathbf{N}$ & Pertemuan & \multicolumn{2}{c}{ Aktivitas yang diamati } & Rata-rata & Kategori \\
\cline { 3 - 4 } & & $\begin{array}{c}\text { Visual } \\
\text { Activiti } \\
\text { es }\end{array}$ & $\begin{array}{c}\text { Oral } \\
\text { Activities }\end{array}$ & & \\
& & & & \\
\hline 1 & Pertemuan I & 100 & 72.2 & 86.1 & Baik \\
2 & Pertemuan II & 83.3 & 100 & 91.7 & Sangat Baik \\
3 & Pertemuan III & 88.9 & 100 & 94.4 & Sangat Baik \\
& & & $\mathbf{9 0 . 8}$ & Sangat Baik \\
\hline
\end{tabular}

Tabel 6. Hasil Penilaian Proses Keterampilan Menyimak Penyebaran

\begin{tabular}{llccccc}
\hline \multirow{2}{*}{ No } & \multicolumn{2}{c}{ Penilaian } & \multicolumn{2}{c}{ Nilai Rata-rata Kelas (\%) } & Rata-rata & Kategori \\
\cline { 2 - 5 } & Menyimak & LKS I & LKS II & LKS III & & \\
\hline 1 & Mengidentifikasi tokoh & 87.5 & 95 & 95 & 92.5 & Sangat Tinggi \\
2 & Mengidentifikasi latar & 90.1 & 82.5 & 85 & 85.9 & Sangat Tinggi \\
3 & Mengidentifikasi tema & 82.5 & 80 & 82.5 & 82 & Sangat Tinggi \\
4 & Mengidentifikasi amanat & 82.5 & 82.5 & 82.5 & 82.5 & Sangat Tinggi \\
5 & Menyimpulkan isi cerita & 90 & 87.5 & 90 & 89.2 & Sangat Tinggi \\
& Rata-rata & 86.5 & 85.5 & 87 & 86.4 & Sangat Tinggi \\
\hline
\end{tabular}


Tabel 5 dan 6 menunjukkan bahwa pertemuan ke-1, ke-2 dan ke-3 pada sekolah penyebaran hasil observasi aktivitas peserta didik memiliki rata-rata $90.8 \%$ denga kategori sangat baik dan hasil penilaian proses Keterampilan Menyimak secara keseluruhan memiliki rata-rata persentase $86.4 \%$ dengan kategori sangat tinggi. Artinya, ketika proses pebelajaran berlangsung, aktivitas peserta didik sangat baik dalam memahami dan menggunakan bahan ajar yang dikembangkan.

Hasil penelitian pengembangan yang telah dilakukan, akan diuraikan lebih lanjut terutama yang berkaitan dengan validitas, praktikalitas, dan efektivitas bahan ajar yang dikembangkan mengambarkan bahwa Isi bahan ajar telah dapat mencapai kompetensi dasar yang diplih. Selain itu, penggunaan bahasa dalam bahan ajar menggunakan kalimat yang sederhana dan mudah dipahami oleh peserta didik. Kalimat demi kalimat menggunakan ejaan yang tepat. Praktikalitas dari bahan ajar yang dikembangkan khususnya untuk keterampilan menyimak berbasis media audio visual sudah bersifat kepraktisan, artinya mudah dalam melaksanakannya, mudah pemeriksaannya, dan dilengkapi dengan petunjuk-petunjuk yang jelas sehingga memudahkan guru dan peserta didik dalam pemakaian perangkat pembelajaran yang digunakan. Selanjutnya, tingkat efektivitas bahan ajar juga diperkuat oleh data pada tahap penyebaran.

\section{SIMPULAN DAN REKOMENDASI}

Simpulan penelitian ini yaitu :

1. Telah dihasilkan bahan ajar menyimak dengan audio visual di kelas V SD dengan kategori sangat valid. Hal ini dapat dilihat berdasarkan hasil validasi bahan ajar menyimak dengan audio visual oleh validator yang telah dilaksanakan. Hasil ini memberi gambaran bahwa bahan ajar menyimak dengan audio visual yang dikembangkan telah valid dan dapat digunakan dalam melaksanakan proses pembelajaran. Dapat dilihat kevalidan bahan ajar dikarenakan bahan ajar yang dikembangkan telah sesuai dengan tuntutan kurikulum, penyajian materi telah sesuai dengan indikator yang dirumuskan dan sesuai dengan perkembangan peseta didik. Selain itu, penggunaan bahasa dalam bahan ajar menggunakan kalimat yang sederhana dan mudah dipahami oleh peserta didik.

2. Praktikalitas bahan ajar menyimak dengan audio visual di kelas V SD secara keseluruhan pada kategori sangat praktis. Hal ini diperoleh dari hasil pengamatan terhadap guru yang mengajar, respon guru, respon peserta didik, dan lembar observasi penggunaan bahan ajar. Hasil ini memberikan gambaran bahwa bahan ajar sangat praktis dan dapat membantu dalam melaksanakan proses pembelajaran. Dapat dilihat kepraktisan respon guru bahwa bahan ajar yang dikembangkan berbeda dengan bahah ajar sebelumnya dan mudah digunakan dalam melaksanakan pembelajaran. Kepraktisan respon peserta didik terlihat dari respon peserta didik yang menyatakan bahwa bahan ajar memudahkan peserta didik dalam menyimak. Media audio visual yang terdapat pada bahan ajar dapat membantu peserta didik membuat deskripsi cerita sehingga dapat dikembangkan menjadi cerita yang utuh dan padu. Selain itu, bahan ajar yang didesain dengan warna yang menarik membuat peserta didik senang dalam melaksanakan pembelajaran. Kepraktisan lembar observasi dapat dilihat dari ketertarikan, antusias, dan keterlibatan aktif peserta didik dalam mengerjakan berbagai tugas yang ada pada bahan ajar.

3. Efektivitas bahan ajar menyimak dengan audio visual di kelas V SD dapat diketahui melalui aktivitas peserta didik, penilaian proses, dan penilaian hasil menulis narasi peserta didik. Aktivitas peserta didik dinyatakan sangat baik dikarenakan hasil pengamatan oleh observer bahwasanya peserta didik tidak kesulitan dalam melaksanakan proses pembelajaran dan dapat mengikutinya dengan baik, baik di sekolah uji coba maupun di sekolah implementasi. Penilaian proses menyimak peserta didik dinyatakan sangat baik dikarenakan peserta didik telah mampu mengikuti tahap-tahap dalam kegiatan pembelajaran. Sedangkan untuk penilaian hasil menyimak peserta didik dinyatakan sangat baik karena pada sekolah uji coba hanya 2 orang peserta didik dari 18 
orang peserta didik yang tidak tuntas pada pertemuan 1, pada pertemuan 2 dan 3 terjadi peningkatan yaitu semua peserta didik tuntas dalam pembelajaran. Pada sekolah implementasi juga dinyatakan sangat baik, karena hanya 1 orang peserta didik dari 18 orang peserta didik yang tidak tuntas pada pertemuan 1, pada pertemuan 2 dan 3 terjadi juga peningkatan, yaitu semua peserta didik tuntas dalam melaksanakan pembelajaran.

Sebagaimana hasil penelitian ini penulis mengajukan beberapa rekomendasi yang berhubungan dengan pengembangan bahan ajar menyimak berbasis media audio visual dengan pengintegrasian pendidikan karakter positif peserta didik yaitu : 1) guru memahami dengan benar pelaksanaan menyimak berbasis media audio visual dengan baik agar tujuan pembelajaran dapat tercapai secara maksimal dengan mengunakan bahan ajar yang dikembangkan; 2) untuk peneliti selanjutnya, penelitian ini dapat dijadikan referensi untuk membuat penelitian yang berhubungan dengan media audio visual.

\section{DAFTAR PUSTAKA}

Abbas, S. (2006). Pembelajaran Bahasa Indonesia yang Efektif di Sekolah Dasar. Jakarta: Depdiknas.

Abidin, Y. (2012). Pembelajaran Bahasa Berorientasi Pendidikan Karakter. Bandung: Refika Aditama.

Alih. (2016). Strategi Pembelajaran Bahasa Indonesia. Bandung: Pustaka Setia.

Allen, K. Eileen dan Lynn R. Marrotz. (2008). Profil Perkembangan Anak. Terjemahan oleh Valentino. 2010. Jakarta: Indeks.

Arief S. \& Sadirman. (2009). Media Pendidikan. Jakarta : PT Raja Grafindo Persada

Arikunto, S. (2006). Prosedur Penelitian: Suatu Pendekatan Praktek. Jakarta: Rineka Cipta.

Azhar, A. (2006). Media Pembelajaran. Jakarta : PT Raja Grafindo Persada

Basrowi dan Suwandi. (2008). Memahami Penelitian Kualitatif. Jakarta : Rineka Cipta

Beni, A. S. (2008). Metode Penelitian. Bandung : Pustaka Setia
Chandra., Arief, D., Kharisma, K., M. Habibi., \& Suriani, A. (2020). Writing Literacy As An Effort To Build Positive Character Of Elementary School Students. Jurnal PAJAR (Pendidikan dan Pengajaran), 4(1), 99-110. DOI http://dx.doi.org/10.33578/pjr.v4i1.7863.

Chandra, Mayarnimar, M Habibi. (2018). Keterampilan Membaca Dan Menulis Permulaan Menggunakan Model Vark Untuk Siswa Sekolah Dasar. Jurnal Inovasi Pendidikan Dan Pembelajaran Sekolah Dasar, 2(1), 72-80. Publication Date $\quad 31 \quad$ Juli 2018. Http://Ejournal.Unp.Ac.Id/Index.Php/Jipp sd/Article/View/100050/100033

Darmansyah. (2011). Strategi Pembelajaran Menyenangkan dengan Humor. Jakarta: Bumi Aksara.

Darnis, A. (2014) The Development Of Narrative Writing Learning Model For Elementary Schools in Padang. Working Paper. FIP UNP, Padang.

Darnis, A. (2018). Pengembangan Literasi Menulis Prosa. Dengan Mengunakan Guided Writing sebagai upaya pecerdasan karakter menuju generasi Emas Untuk Siswa SD. Project Report. PGSD FIP UNP, Padang http://repository.unp.ac.id/27171/

Depdiknas. (2006). Kurikulum Tingkat Satuan Pendidikan. Jakarta : Depdiknas

Depdiknas. (2006). Panduan Penyusunan Kurikulum Tingkat Satuan Pendidikan. Jakarta: Depdiknas.

Djago, T. (1991). Pendidikan Bahasa Indonesia I. Jakarta : Departemen Pendidikan dan Kebudayaan Proyek Pembinaan Tenaga Kependidikan Pendidikan Tinggi

Djago, T. (2008). Kamus Besar Bahasa Indonesia Pusat Bahasa. Jakarta: Gramedia Pustaka Utama.

Ghazali, A. \& Syukur. (2010). Pembelajaran Keterampilan Berbahasa dengan Pendekatan Komunikatif-Interaktif. Bandung: Refika Aditama.

Gulo, W. (2008). Strategi Belajar Mengajar. Jakarta: Grasindo.

Hamdani. (2011). Strategi Belajar Mengajar. Bandung: Pustaka Setia. 
Hartinah, S. (2010). Pengembangan Peserta Didik. Bandung: Refika Aditama.

Haryadi dan Zamzami. (1997). Peningkatan Keterampilan Berbahasa Indonesia. Jakarta : Departemen Pendidikan dan Kebudayaan Direktorat Jenderal Pendidikan Tinggi Bagian Proyek Pengembangan Pendidikan Guru Sekolah Dasar

Hujair, S. (2009). Media Pembelajaran. Yogyakarta : Safiria Insania Press

Isah, C., dan Hodijah. (2008). Kemampuan Berbahasa Indonesia di SD. Bandung : UPI Press

Iskandarwassid dan Sunendar, D. (2008). Strategi Pembelajaran Bahasa. Bandung: Rosdakarya.

Kunandar. (2011). Guru Profesional Implementasi Kurikulum Tingkat Satuan Pendidikan (KTSP) dan Sukses dalam Sertifikasi Guru. Jakarta: RajaGrafindo Persada.

Mohammad, J. (2011). Implementasi PAIKEM dari Behavioristik sampai Konstruktivistik sebuah Pengembangan Pembelajaran Berbasis CTL. Jakarta : Prestasi Pustakaraya

Mubin dan Cahyadi, A. (2006). Psikologi Perkembangan. Ciputat: Quantum Teaching.

Muhaimin, dkk. (2009). Pengembangan Model Kurikulum Tingkat Satuan Pendidikan (KTSP) pada Sekolah dan Madrasah. Jakarta: Rajawali Pers.

Muhardila, F., Sulaeman, Y., \& Chandra, C. (2020). Pengembangan LKS Tematik Bahasa Indonesia Kelas V Melalui Kegiatan Lesson Study Di Sekolah Dasar. Jurnal Cakrawala Pendas, 6 (1), Publication date 2 Januari 2020. http://www.jurnal.unma.ac.id/index.php/C P/article/view/1559

Mulyasa, E. (2009a). Implementasi Kurikulum Tingkat Satuan Pendidikan Kemandirian Guru dan Kepala Sekolah. Jakarta: Bumi Aksara.

Muslich, M. (2011a). KTSP Dasar Pemahaman dan Pengembangan. Jakarta: Bumi Aksara.
Nana, S., dan Ibrahim. (2007). Penelitian dan Penilaian Pendidikan. Bandung : Sinar Baru Alqensindo

Ngalim, P. (2006). Prinsip-prinsip dan Teknik Evaluasi Pengajaran. Bandung: PT Remaja Rosdakarya

Pertiwi, A., \& Taufina, T. (2019). Model Experiential Learning Dalam Pembelajaran Menulis Laporan Pengamatan Siswa Bagi Kelas V Sekolah Dasar. E-Journal Pembelajaran Inovasi, Jurnal Ilmiah Pendidikan Dasar, 7(9). Http://103.216.87.80/Students/Index.Php/ Pgsd/Article/View/6867

Putra, N. (2012). Research and Development, Penelitian dan Pengembangan: Suatu Pengantar. Jakarta: Raja Grafindo Persada.

Resmini, N., dan Dadan, J. (2007). Pendidikan Bahasa dan Sastra Indonesia di Kelas Tinggi. Bandung: UPI Press.

Rosdiana, Y., dkk. (2009). Bahasa dan Sastra Indonesia di SD. Jakarta: Universitas Terbuka

Rubin, D. (1995). Teaching Elementary Language Art an Integrated Approach. USA: Allyn and Bacon.

Saddhono, K., dan St.Y. Slamet. (2012). Meningkatkan Keterampilan Berbahasa Indonesia (Teori dan Aplikasi). Bandung: Karya Putra Darwati.

Saleh, A. (2006). Pembelajaran Bahasa Indonesia yang Efektif di Sekolah Dasar. Jakarta : Departemen Pendidikan Nasional Direktorat Jenderal Pendidikan Tinggi Direktorat Ketenagaan

Sanjaya, W. (2009). Perencanaan dan Desain Sistem Pembelajaran. Jakarta: Prenada Media Group.

Santrock, J. W. (2007). Perkembangan Anak. Terjemahan oleh Mila Rachmawati dan Anna Kuswanti. 2007. Jakarta: Erlangga.

Semiawan, C. R. (2008). Catatan Kecil tentang Penelitian dan Pengembangan Ilmu Pengetahuan. Jakarta: Kencana Prenada Media Group.

Setyosari, P. (2010). Metode Penelitian Pendidikan dan Pengembangan. Jakarta: Kencana Prenada Media Group. 
Sudjana, H. D. (2010). Metode dan Teknik Pembelajaran Partisipatif. Bandung : Falah Production.

Sugiyono. (2009). Metode Penelitian Pendidikan Pendidikan Kuantitatif, Kualitatif, dan $R \& D$. Bandung: Alfabeta.

Suparno dan Mohamad, Y. (2007). Keterampilan Dasar Menulis. Jakarta: Universitas Terbuka.

Surapranata, S. (2006). Analisis, Validitas, Reliabilitas, dan Interpretasi Hasil Tes Implementasi Kurikulum 2004. Bandung: Rosdakarya.

Susanto. (2007). Pengembangan KTSP dengan Perspektif Manajemen Visi. Jakarta: Matapena.

Syaiful, B. D., dkk. (2006). Strategi BelajarMengajar. Jakarta : PT Rineka Cipta

Taufina. (2015). Keterampilan Berbahasa dan Apresiasi Sastra Indonesia di SD. Padang: Sukabina Press

Taufina dan Chandra. (2017). Developing The Big Questions And Bookmark Organizers (Bqbo) Strategy-Based Literacy Reading Learning Materials In The 4th Grade Of Elementary School, The 9th International Conference For Science Educators And Teachers (ICSET 2017). Retrieved 29 April $2018 \quad$ From Https://Www.Atlantispress.Com/Proce Edings/Icset-17/25886637

Taufina, Dkk. (2018). Development Of Teaching Material For Narrative Writing Using Graphic Organizer Type Circle Organizer In Elementary School. Advances In Social Science, Education And Humanities Research International Conference On Language, Literature, And Education. Vol 263. Di Ambil Pada Tanggal 22 Desember 2018

Dari

Http://Journal.Ipts.Ac.Id/Index.Php/ED/A rticle/View/846

Taufina, Dkk. (2018). Implementation Of Character Education And Improvement of Skill Writing Descriptive In Class 4 SDN 075043 Oladano. Jurnal Aplikasi IPTEK Indonesia. Vol 2 No 2. Di Ambil Pada Tanggal 22 Desember 2018 Dari
Http://Bk.Ppj.Unp.Ac.Id/Index.Php/Aipte kin/Article/View/139

Taufina. (2016). Mozaik Keterampilan Berbahasa Di Sekolah Dasar. Bandung: CV. Angkasa.

Tomkins, G. E., dan Hoskisson, K. (1991). Language Arts Content and Teaching Strategies. New York: Macmillan Publishing Company.

Trianto. (2007). Model Pembelajaran Terpadu dalam Teori dan Praktek. Jakarta: Prestasi Pustaka.

Umar. (2006). Pendidikan Guru Berdasarkan Pendekatan Kompetensi. Jakarta; Bumi Aksara.

Uno, H. B. (2007). Model Pembelajaran Menciptakan Proses Belajar Mengajar yang Kreatif dan Efektif. Jakarta: Bumi Aksara.

Wena, M. (2009). Strategi Pembelajaran Inovatif Kontemporer suatu Tinjauan Konseptual Operasional. Jakarta: Bumi Aksara.

Weriyanti, F Firman, T Taufina, A Zikri . (2020). Pengembangan Bahan Ajar Tematik Terpadu Dengan Strategi Question Student Have Di Sekolah Dasar. Jurnal Basicedu, $4 \quad$ (2), $476 \quad$ - 483. Http://Www.Jbasic.Org/Index.Php/Basice du/Article/View/374

Wina, S. (2010). Strategi Pembelajaran Berorientasi Standar Proses Pendidikan. Jakarta : Prenada Media Group

Yamin, M. (2007). Kiat Membelajarkan Siswa. Jakarta: Gaung Persada Press.

Yunismar. (2019). Keefektifan Strategi Menulis Terbimbing untuk Meningkatkan Keterampilan Mengarang Narasi. Jurnal PAJAR (Pendidikan dan Pengajaran), 3(6), 1255-1263. DOI http://dx.doi.org/10.33578/pjr.v3i6.7887.

Yusuf L. N, Syamsu dan Nani M.Sugandhi. (2012). Perkembangan Peserta Didik. Jakarta: Raja Grafindo Persada. 